\title{
Chemical composition of Desulfovibrio desulfuricans lipid A
}

\author{
Daniel Wolny $\cdot$ Jolanta Lodowska $\cdot$ \\ Marzena Jaworska-Kik • Sławomir Kurkiewicz • \\ Ludmiła Węglarz · Zofia Dzierżewicz
}

Received: 29 June 2010/Revised: 2 September 2010/Accepted: 15 September 2010/Published online: 27 October 2010

(C) The Author(s) 2010. This article is published with open access at Springerlink.com

\begin{abstract}
Lipopolysaccharides also called endotoxins are an integral component of the outer membrane of Gramnegative bacteria. When released from the bacterial surface, they interact with a host immune system, triggering excessive inflammatory response. Lipid A is the biologically most active part of endotoxin, and its activity is modulated by the quantity, quality and arrangement of its fatty acids. Desulfovibrio desulfuricans is sulfate-reducing, Gram-negative bacterium that is supposed to be opportunistic pathogens of humans and animals. In the present study, chemical composition of lipid A from various strains of $D$. desulfuricans was analyzed by gas chromatography/ mass spectrometry. It was found that the fatty acid component of the lipid A contains dodecanoic, tetradecanoic, 3-hydroxytetradecanoic and hexadecanoic acids, and its carbohydrate core is composed of glucosamine. The analysis of 3-acyloxyacyl residue of the lipid A revealed the presence of amide-bound 3-(dodecanoyloxy)tetradecanoic and 3-(hexadecanoyloxy)tetradecanoic acids and esterbound 3-(tetradecanoyloxy)tetradecanoic acid. It was concluded that both fatty acid and 3-acyloxyacyl residue
\end{abstract}

Communicated by Friedrich Widdel.

D. Wolny $(\bowtie) \cdot$ M. Jaworska-Kik $\cdot$ Z. Dzierżewicz Department of Biopharmacy, Faculty of Pharmacy, Medical University of Silesia, Narcyzow 1 St.,

41-200 Sosnowiec, Poland

e-mail: dwolny@sum.edu.pl

J. Lodowska $\cdot$ L. Węglarz

Department of Biochemistry, Faculty of Pharmacy,

Medical University of Silesia, Katowice, Poland

S. Kurkiewicz

Department of Instrumental Analysis, Faculty of Pharmacy, Medical University of Silesia, Katowice, Poland profiles of the lipid A from the studied bacteria were similar to those of E. coli and S.enterica.

Keywords Lipid A - Desulfovibrio desulfuricans . Endotoxin · Lipopolysaccharide

\section{Introduction}

Lipopolysaccharide (LPS), also called endotoxin, is an integral component of the outer membrane of all Gramnegative bacteria. LPS, liberated during cell lysis or division, interacts with the immune system components, especially monocytes and macrophages. In a bloodstream, it can trigger an excessive immune response of the infected macroorganism leading to the endotoxic shock and even death (Erridge et al. 2002).

Endotoxin consists of three regions: antigen-O, core and lipid A. Lipid A is the center of LPS biological activity and interacts with endotoxin receptors on the surface of immune cells, stimulating them to the synthesis and release of various inflammatory mediators such as interleukins, tumor necrosis factor $\alpha$ (TNF- $\alpha$ ), interferons and prostaglandins (Erridge et al. 2002). Lipid A is considered to be the most structurally conservative part of bacterial endotoxin. It is composed of $\beta(1 \rightarrow 6)$ linked disaccharide core, usually containing glucosamine, with phosphate groups (substituted in some cases) localized at the positions 1 and $4^{\prime}$ and ester- and amide-bound fatty acids at the positions 2 , $3,2^{\prime}$ and $3^{\prime}$. The fatty acids linked directly to glucosamine core are most often 3-hydroxy fatty acids, which hydroxy groups can be substituted by other fatty acids forming 3 -acyloxyacyl residues (Caroff and Karibian 2003). The quantity, quality and arrangement of fatty acids within lipid A as well as the chemical nature of substituents at positions 
1 and $4^{\prime}$ of the disaccharide core affect biological activity of endotoxin (Rietschel et al. 1994; Erridge et al. 2002).

The species Desulfovibrio desulfuricans belongs to Gram-negative, sulfate-reducing bacteria. They are curved, mobile, anaerobic microorganisms, which are characterized by the presence of desulfoviridin-type dissimilatory sulfite reductase in their cell and ability to oxidize simple organic substrates such as lactate or pyruvate to acetate (Barton and Hamilton 2007; Shukla and Reed 2000). D. desulfuricans bacteria are widespread in natural environment, including most types of water, sewage, mud and soil, as well as human and animal alimentary tracts (Fox et al. 1994; Goldstein et al. 2003). However, they are considered to be the opportunistic pathogens. It has been suggested that $D$. desulfuricans could be an etiologic factor of various types of enteritis, Crohn's disease and ulcerative colitis (Baron et al. 1992). Some cases of bacteremia caused by these bacteria have also been reported (Porschen and Chan 1977; Goldstein et al. 2003).

In the present study, total, ester- and amide-bound fatty acids of $D$. desulfuricans lipopolysaccharide as well as the chemical nature of 3-acyloxyacyl substituents have been investigated.

\section{Materials and methods}

Bacterial strains, culture conditions and endotoxin isolation

The type strain DSM 642 (German Collection of Microorganisms and Cell Cultures, Braunschweig, Germany) and five wild strains of $D$. desulfuricans, isolated from feces (DV/B, DV/C, DV/H, DV/I) and biopsy specimens (DV/I/ 1) of patients suffering from various gastrointestinal disorders (Dzierżewicz et al. 1996), were examined. Bacteria were cultured in the Postgate's pyruvate medium for 10 days $\left(30^{\circ} \mathrm{C}, \mathrm{pH}=7.5\right)$ under anaerobic conditions $\left(80 \% \mathrm{~N}_{2}, 10 \% \mathrm{H}_{2}\right.$ i $10 \% \mathrm{CO}_{2}$, MACS chamber, Anaerobic Workstation dW Scientific, West Yorkshire, England) (Postgate 1984). Endotoxins were isolated from bacterial cells by the water-phenol method described by Johnson and Perry (1976).

Determination of lipid A fatty acids

Ester-bound, amide-bound and total fatty acids of the lipid A were determined according to the procedures of Wollenweber and Rietschel (1990). To determine the total fatty acid profile, bacterial LPS was treated with $\mathrm{HCl}$ and then with methanolic $\mathrm{HCl}$, and the fatty acid methyl esters formed were analyzed by gas chromatography coupled with mass spectrometry (GC/MS).
The ester-bound fatty acids were selectively liberated from endotoxin by methanolic $\mathrm{NaOCH}_{3}$ as the corresponding methyl esters and subjected to GC/MS analysis. LPS treatment with methanolic $\mathrm{NaOCH}_{3}$ yielded de-Oacetylated LPS containing amide-bound fatty acids that were further analyzed using the procedure described for total fatty acid determination (Wollenweber and Rietschel 1990).

Analysis of 3-acyloxyacyl residues

3-Acyloxyacyl substituents present in D. desulfuricans lipid A were analyzed by GC/MS after their derivatization according to the procedure of Wollenweber and Rietschel (1990). Lipid A was obtained by mild acid hydrolysis of LPS $\left(1 \%\right.$ acetic acid, $\left.1 \mathrm{~h}, 100^{\circ} \mathrm{C}\right)$, and amide-bound 3 -acyloxyacyl residues were liberated from it in the form of methyl esters after conversion to acid-labile imidate by methyl iodide in the presence of silver salts. Esterbound 3-acyloxyacyl substituents were liberated as well, due to the presence of water. Therefore, to distinguish between ester- and amide-bound compounds, the procedure was conducted once in the presence and once in the absence of methyl iodide.

\section{Determination of carbohydrate in lipid A}

Carbohydrates were analyzed after derivatization to acetylated methyl glycosides. Lipid A was separated from LPS by mild acid hydrolysis ( $1 \%$ acetic acid, $\left.1 \mathrm{~h}, 100^{\circ} \mathrm{C}\right)$. After centrifugation $(6,500 \times g, 30 \mathrm{~min})$, lipid A residue was dried over $\mathrm{P}_{2} \mathrm{O}_{5}$ and then subjected to methanolysis. Glycosides were acetylated and analyzed by GC/MS (Rybka and Gamian 2006).

\section{GC/MS analysis}

The analyses of fatty acid and carbohydrate derivatives were carried out on a Hewlett-Packard gas chromatograph (HP5890 II) coupled with mass spectrometer (HP5989A). HP5-MS capillary column $(60 \mathrm{~m}$, i.d. $0.32 \mathrm{~mm}$, film thickness $0.25 \mu \mathrm{m}$, Agilent Technologies) was used. Samples of total, ester- and amide-bound fatty acid methyl esters were injected onto the column at $60^{\circ} \mathrm{C}$ in the splitless mode. The oven temperature was programed from 60 to $100^{\circ} \mathrm{C}$ at $10^{\circ} \mathrm{C} / \mathrm{min}$, then at $5^{\circ} \mathrm{C} / \mathrm{min}$ up to $260^{\circ} \mathrm{C}$ which was maintained for $13 \mathrm{~min}$. The samples of 3-acyloxyacyl derivatives were injected onto the column at $50^{\circ} \mathrm{C}$ in the splitless mode. The oven temperature was programed from 50 to $160^{\circ} \mathrm{C}$ at $20^{\circ} \mathrm{C} / \mathrm{min}$, then at $3^{\circ} \mathrm{C} / \mathrm{min}$ up to $290^{\circ} \mathrm{C}$ which was maintained for $25 \mathrm{~min}$. Acetylated methyl glycosides were injected on column at $50^{\circ} \mathrm{C}$ in the splitless mode. The oven temperature was programed from 50 to 
$160^{\circ} \mathrm{C}$ at $20^{\circ} \mathrm{C} / \mathrm{min}$, then at $4^{\circ} \mathrm{C} / \mathrm{min}$ up to $260^{\circ} \mathrm{C}$ which was maintained for $30 \mathrm{~min}$. Helium (0.1 MPa) was used as a carrier gas. The transfer line temperature was $250^{\circ} \mathrm{C}$, the ion source $200^{\circ} \mathrm{C}$ and quadrupole $100^{\circ} \mathrm{C}$. The compounds were ionized by electron impact $(70 \mathrm{eV})$.

\section{Statistics}

Numerical cluster analysis was used to determine the similarity of fatty acid profiles of $D$. desulfuricans strains. A dendrogram based on the Pearson correlation coefficient as the distance measure was generated. Statistical analysis was performed using Statistica 8.0 software.

\section{Results}

Total fatty acids

GC/MS analysis of total fatty acids of $D$. desulfuricans LPS showed that these components were in the C12-C18 range (Table 1, Fig. 1). The predominant fatty acid was 3-hydroxytetradecanoic acid (3-OH 14:0), which under derivatization conditions has been transformed not only to its methyl ester but also to the methyl esters of 3-metoxytetradecanoic acid (3-OMe 14:0) and tetradecenoic acid (14:1). Furthermore, dodecanoic (12:0), tetradecanoic (14:0) and hexadecanoic acid (16:0) methyl esters were found in significant amounts among the analyzed compounds. The derivatives of other fatty acids were also present, but their content was substantially lower. The amount of each of four major fatty acid methyl esters, expressed as the percentage of total amount of these derivatives, was used to determine the similarity of fatty acid profiles of the investigated strains. The numerical cluster analysis showed that fatty acid profiles of all strains were very similar to each other (98.92\% similarity) (Fig. 2).

Ester- and amide-bound fatty acids

The fatty acid analysis showed that 12:0, 14:0, 3-OH 14:0 and 16:0 acids were ester-bound in the analyzed lipid A. The peaks of their derivatives predominate on the obtained chromatograms (Fig. 3a). The peak of 3-OMe 14:0 acid methyl ester was formed during the reaction with methanolic $\mathrm{NaOCH}_{3}$, from 3-OH 14:0 compound substituted at its hydroxy group by the other fatty acid. Therefore, it can be suggested that this fatty acid is a constituent of ester-bound 3-acyloxyacyl residue. Other low-intensity peaks originated probably from the contamination of LPS extracts by membrane lipids, since they have also been observed during total fatty acid analysis. The GC/MS analysis showed that 3-OH 14:0 was the only amide-bound fatty acid present in the studied LPS (Fig. 3b). The peaks of 14:1 and 3-OMe 14:0 derivatives, seen on chromatograms, are artifacts formed from 3-OH 14:0 fatty acid during derivatization procedure.

\section{3-Acyloxyacyl residues}

3-(dodecanoyloxy)tetradecanoic, 3-(tetradecanoyloxy)tetradecanoic and 3-(hexadecanoyloxy)tetradecanoic acids were identified in lipid A of D. desulfuricans (Fig. 4a). Derivatization without $\mathrm{CH}_{3} \mathrm{I}$ showed that only 3-(tetradecanoyloxy)tetradecanoic acid was ester-linked to the lipid A glucosamine core, and the others were found to be amide-bound (Fig. 4b). Due to the lack of spectra of 3 -acyloxyacyl residues methyl esters in the mass spectra database (Wiley 7), identification of the compounds was

Table 1 Lipopolysaccharide fatty acid composition of D. desulfuricans strains

\begin{tabular}{|c|c|c|c|c|c|c|}
\hline \multirow[t]{2}{*}{ Fatty acid } & \multicolumn{6}{|l|}{ Strain } \\
\hline & $\mathrm{DV} / \mathrm{B}$ & $\mathrm{DV} / \mathrm{C}$ & $\mathrm{DV} / \mathrm{H}$ & $\mathrm{DV} / \mathrm{I}$ & $\mathrm{DV} / \mathrm{I} / 1$ & DSM 642 \\
\hline $12: 0$ & $2.8 \pm 0.4$ & $9.4 \pm 0.1$ & $8.8 \pm 0.3$ & $10.4 \pm 0.2$ & $8.5 \pm 0.1$ & $11.6 \pm 0.1$ \\
\hline $14: 0$ & $16.3 \pm 1.1$ & $16.5 \pm 0.1$ & $17.7 \pm 0.3$ & $16.2 \pm 0.3$ & $14.8 \pm 0.2$ & $18.43 \pm 0.03$ \\
\hline $15: 0$ & ND & $0.56 \pm 0.04$ & $0.44 \pm 0.02$ & $1.3 \pm 0.1$ & $1.6 \pm 0.1$ & ND \\
\hline ai 15:0 & ND & ND & $2.7 \pm 0.1$ & $1.1 \pm 0.1$ & $1.4 \pm 0.1$ & $1.97 \pm 0.01$ \\
\hline $3-\mathrm{OH} 14: 0$ & $64.04 \pm 1.80$ & $46.03 \pm 0.33$ & $53.2 \pm 0.2$ & $51.2 \pm 0.6$ & $44.0 \pm 0.3$ & $55.1 \pm 0.5$ \\
\hline i16:0 & ND & ND & $3.1 \pm 0.1$ & ND & ND & $1.1 \pm 0.2$ \\
\hline $16: 1$ & $1.4 \pm 0.3$ & $2.7 \pm 0.7$ & $2.2 \pm 0.1$ & $1.8 \pm 0.1$ & $2.4 \pm 0.2$ & $0.9 \pm 0.2$ \\
\hline $16: 0$ & $10.2 \pm 0.4$ & $12.2 \pm 0.2$ & $7.5 \pm 0.2$ & $10.6 \pm 0.5$ & $12.0 \pm 0.2$ & $6.97 \pm 0.03$ \\
\hline ai17:0 & ND & ND & ND & ND & $0.50 \pm 0.02$ & $0.95 \pm 0.05$ \\
\hline $18: 1 \mathrm{a}$ & $2.8 \pm 0.2$ & $3.4 \pm 0.2$ & $1.5 \pm 0.1$ & $3.82 \pm 0.04$ & $4.6 \pm 0.1$ & $1.6 \pm 0.1$ \\
\hline $18: 1 b$ & $1.6 \pm 0.2$ & $7.7 \pm 0.1$ & $2.6 \pm 0.2$ & $2.0 \pm 0.1$ & $3.48 \pm 0.05$ & $1.04 \pm 0.04$ \\
\hline $18: 0$ & $0.7 \pm 0.1$ & $1.6 \pm 0.3$ & $0.43 \pm 0.04$ & $1.5 \pm 0.8$ & $6.7 \pm 0.5$ & $0.30 \pm 0.01$ \\
\hline
\end{tabular}

The values are expressed as $\%$ of total identified fatty acids and are given as the mean \pm SD of three separate analyses. $N D$ not detected 


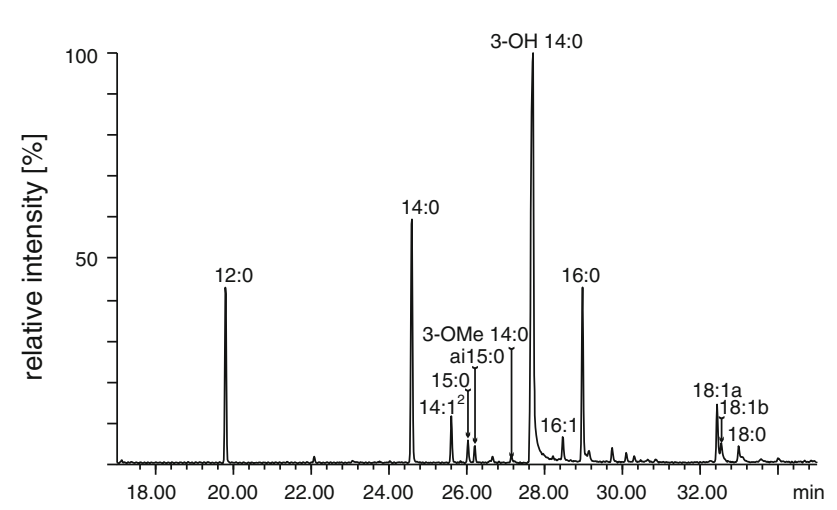

Fig. 1 Chromatogram of total fatty acid derivatives obtained from lipid A of D. desulfuricans intestinal strain DV/I

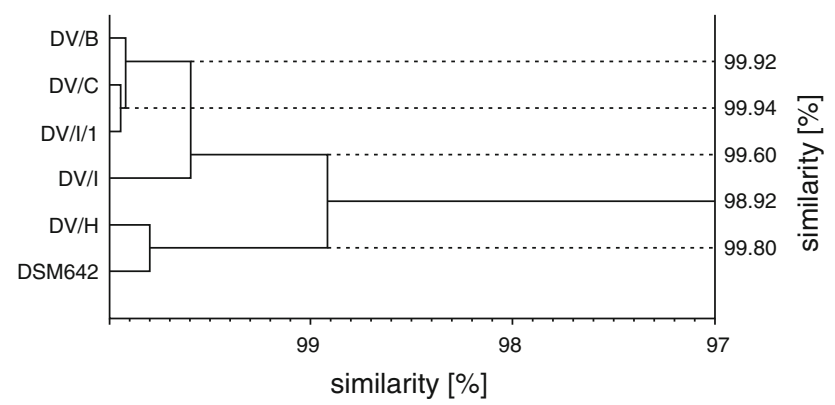

Fig. 2 Dendrogram generated by numerical cluster analysis of lipid A fatty acid profiles of the investigated $D$. desulfuricans strains

performed by comparison with theoretical fragmentation and with the spectra found in other papers (Wollenweber et al. 1982, 1983, 1984). The obtained mass spectra of 3 -acyloxyacyl methyl esters are shown in Fig. 5. Since molecular ions $\left(\mathbf{M}^{+}\right)$at $\mathrm{m} / \mathrm{z}=440,468$ and 496 were characteristic for each of the residues, they were used as a major identification criterion. Ions at $\mathrm{m} / \mathrm{z}=241$ and 257 , present in all the spectra, allowed the identification of 3-hydroxytetradecanoic acid, whereas substituents of 3-OH 14:0 were identified by the presence of characteristic ions at $\mathrm{m} / \mathrm{z}=183$ (for $\left.\mathrm{CH}_{3}\left(\mathrm{CH}_{2}\right)_{10} \mathrm{CO}\right), \mathrm{m} / z=211\left(\mathrm{CH}_{3}\left(\mathrm{CH}_{2}\right)_{12} \mathrm{CO}\right.$ ) and $m / z=239\left(\mathrm{CH}_{3}\left(\mathrm{CH}_{2}\right)_{14} \mathrm{CO}\right)$ (Fig. 5).

\section{Carbohydrate component of lipid A}

After methanolysis and acetylation of lipid A, methyl 3,4,6-tri-O-acetyl-2-acetamido-2-deoxy-glucopyranoside was detected by GC/MS (Fig. 6). These findings proved that carbohydrate component of the studied lipids $\mathrm{A}$ is composed of glucosamine.

\section{Discussion}

D. desulfuricans are bacteria commonly found in natural anaerobic environment. They are suggested to be the
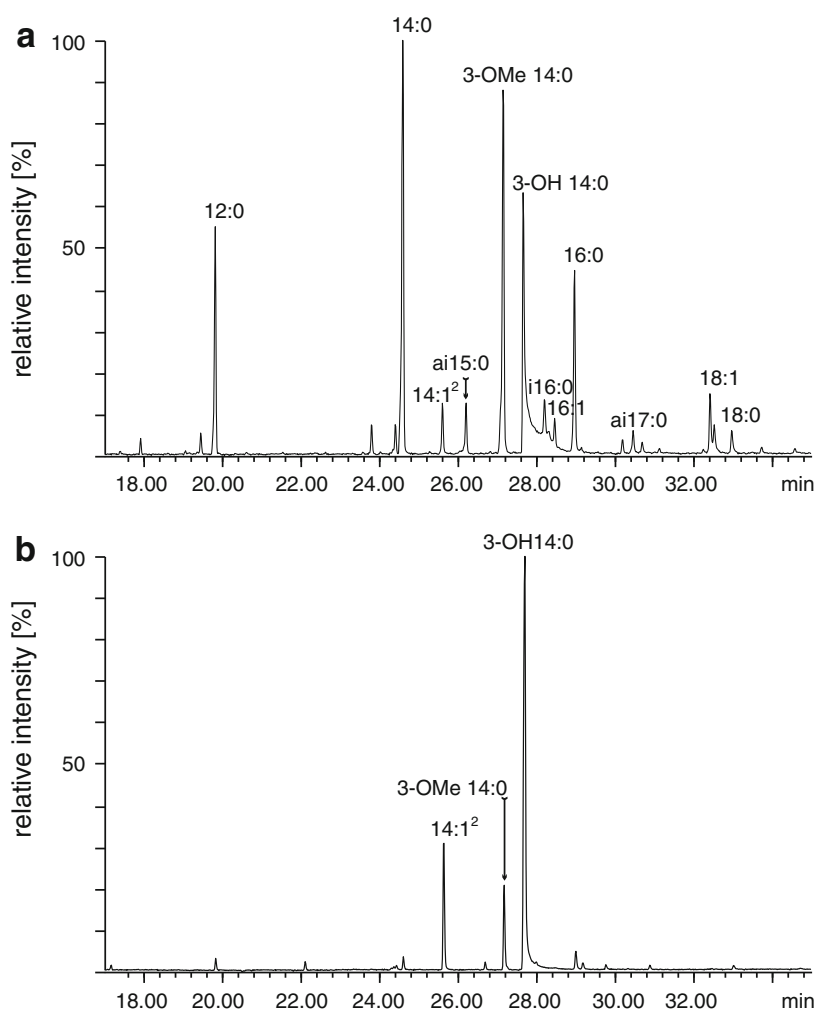

Fig. 3 Chromatograms of ester- (a) and amide-bound (b) fatty acid derivatives of type strain of $D$. desulfuricans

opportunistic pathogens of humans and animals (Gibson et al. 1991; McDougall et al. 1997; Shukla and Reed 2000; Goldstein et al. 2003). They belong to Gram-negative bacteria, which are characterized by the presence of LPS on the cell surface. LPS is recognized by immune system of bacteria-infected organism as "pathogen-associated molecular pattern" that leads to excessive and rapid immunological response (Ulmer et al. 2002). The present knowledge about the structure of these bacteria lipid A, the biological center of endotoxin, is insufficient.

A $98.92 \%$ similarity of lipid A fatty acid profiles of investigated bacterial strains indicates that this region of LPS is very conservative structurally. The predominant fatty acid in this structure appeared to be 3-OH 14:0. Edlund et al. (1985) found 3-OH i17:0 as the only 3-hydroxy fatty acid present in D. desulfuricans LPS, whereas Gaylarde and Beech (1996) did not identify any.

The 12:0, 14:0 and 16:0 fatty acids were abundant in the analyzed endotoxin; however, minor quantities of other fatty acids (15:0, ai15:0, i16:0, 16:1, ai17:0, 18:1 and 18:0) were also detected. Gaylarde and Beech (1996) identified 9-octadecenoic, tetracosenoic, heptadecenoic, 10-octadecenoic, eicosenoic and 8-octadecynoic fatty acids, whereas Edlund et al. (1985) identified 28 fatty acids (C14-C19), both straight- and branched-chain, saturated and unsaturated in $D$. desulfuricans LPS. Lipid A is structurally 


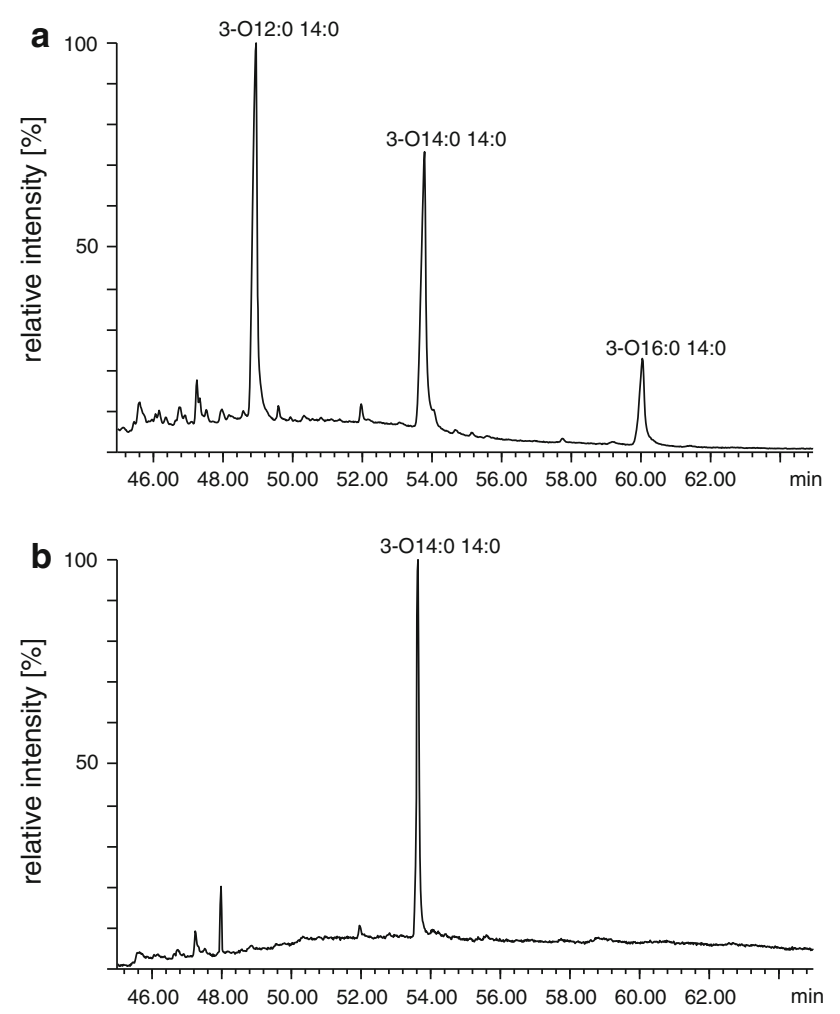

Fig. 4 Chromatograms of 3-acyloxyacyl derivatives of lipid A obtained in the presence (a) and absence (b) of methyl iodide

conservative, and only its tetra-, penta-, hexa- and heptaacyl structures have been identified so far (Lodowska et al. 2007), so the quantity of different fatty acids in this structure is limited. Therefore, only fatty acids found in significant amounts in the analyzed samples (12:0, 14:0, 3-OH 14:0 and 16:0) have been considered as lipid A constituents. The remaining fatty acids were probably co-isolated with endotoxin from cytoplasmic membrane. The fact that these fatty acids were ester-linked and were identified as cellular fatty acids (Dzierżewicz et al. 1996) also argues for their nonendotoxin origination. Moreover, the analysis of 3-acyloxyacyl residues also indicates only 12:0, 14:0, 3-OH 14:0 and 16:0 as fatty acids of the studied lipid A.

The 3-OH 14:0 fatty acid was the only amide-bound one in lipid A of the investigated strains. This fatty acid was also identified among the ester-bound fatty acids. The 3-OH 14:0 methyl ester as well as 3-OMe 14:0 methyl ester was formed under derivatization procedure, and the relative intensity of chromatographic peaks of these derivatives was similar. Therefore, ester-bound 3-OH 14:0 fatty acid was found in lipid A both unsubstituted and as a part of 3-acyloxyacyl residue. Glucosamine was the only carbohydrate compound found in investigated structure. Therefore, the 3-OH 14:0 is suggested to be both ester- and amide-bound to the lipid A glucosamine core, whereas the other fatty acids found in studied structures are its
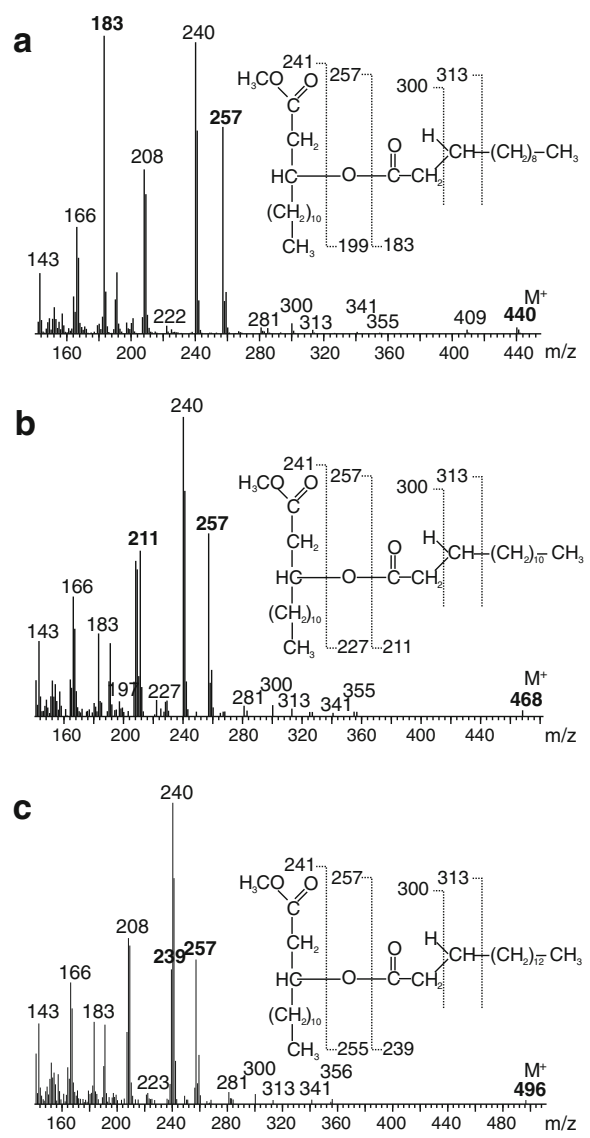

Fig. 5 Mass spectra and fragmentation pattern of 3-(dodecanoyloxy) tetradecanoic (a), 3-(tetradecanoyloxy)tetradecanoic (b) and 3-(hexadecanoyloxy)tetradecanoic (c) acid methyl esters

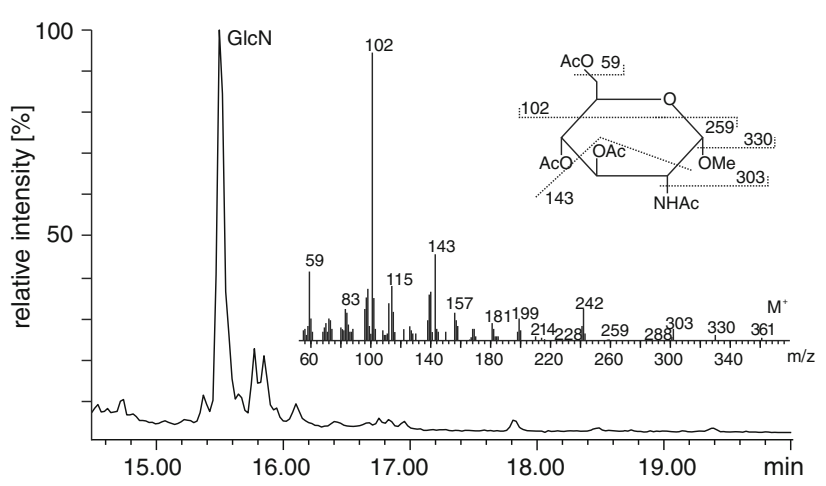

Fig. 6 Chromatogram, mass spectrum and fragmentation pattern of acetylated glucosamine methyl glycoside

substituents. That assumption was confirmed by the findings of GC/MS analysis of 3-acyloxyacyl residues.

Amide-bound 3-(dodecanoyloxy)tetradecanoic, 3-(hexadecanoyloxy)tetradecanoic and ester-bound 3-(tetradecanoyloxy)tetradecanoic acids were identified in lipid A of D. desulfuricans bacteria. The low-intensity peak of 3-(hexadecanoyloxy)tetradecanoic derivative might indicate 
that $16: 0$ is substituted unstoichiometrically to 3 -hydroxy acid. Therefore, it can be supposed that in endotoxins of $D$. desulfuricans, two forms of lipid A (hexa- and heptaacyl lipid A) coexist. This phenomenon is observed in pathogenic bacteria such as Salmonella enterica, Escherichia coli, Legionella pneumophila or Bordetella bronchiseptica (Raetz et al. 2007). The coexistence of two forms of lipid A differing in the quantity of attached fatty acids has an effect on the biological activity of this structure. Heptaacyl lipid A is 100 times less active than a hexaacyl form of this structure (Rietschel et al. 1994; Erridge et al. 2002).

The profile of fatty acids and 3-acyloxyacyl residues of the investigated bacteria has been found to be similar to that of E. coli and S. enterica (Imoto et al. 1983; Wollenweber et al. 1984). Studies of Węglarz et al. (2006) showed that $D$. desulfuricans LPS induced human monocytes to the synthesis and secretion of TNF- $\alpha$ at similar level as endotoxin of E. coli and S. enterica. LPS isolated from investigated bacteria also induced endothelial cells to the secretion of IL-6 and IL-8, and expression of E-selectin and VCAM-1 (Węglarz et al. 2003b). However, these molecules did not affect IL-8 secretion by Caco-2 cells (Węglarz et al. 2003a). Dzierżewicz et al. (2005) stated that incubation of fibroblasts in the presence of $D$. desulfuricans endotoxin caused the apoptosis of these cells. It should be mentioned that the biological activity of endotoxin results not only from lipid A structure but is also influenced by length and chemical composition of its O-antigen component. Dzierżewicz et al. (2005) suggest that there is intrastrain diversity with respect to mean molecular masses of D. desulfuricans LPS, caused by the differences in length of their carbohydrate components. It can be supposed that the release of large quantities of endotoxin by $D$. desulfuricans bacteria in a bloodstream may trigger a potent immune system response and evoke endotoxic shock.

Conflict of interest The authors declare that they have no conflict of interest.

Open Access This article is distributed under the terms of the Creative Commons Attribution Noncommercial License which permits any noncommercial use, distribution, and reproduction in any medium, provided the original author(s) and source are credited.

\section{References}

Baron EJ, Bennion R, Thompson J, Strong C, Summanen P, McTeague M, Finegold SM (1992) A microbiological comparison between acute and complicated appendicitis. Clin Infect Dis 14:227-231

Barton LL, Hamilton WA (2007) Suphate-reducing bacteria. Cambridge University Press, Cambridge

Caroff M, Karibian D (2003) Structure of bacterial lipopolysaccharides. Carbohydr Res 338:2431-2447
Dzierżewicz Z, Cwalina B, Kurkiewicz S, Chodurek E, Wilczok T (1996) Intraspecies variability of cellular fatty acids among soil and intestinal strains of Desulfovibrio desulfuricans. Appl Environ Microbiol 62:3360-3365

Dzierżewicz Z, Orchel A, Komarska-Szostak A, Wawszczyk J, Węglarz L, Szczerba J, Wilczok T (2005) Biological activity of endotoxins isolated from Desulfovibrio desulfuricans species. Ann Acad Med Siles 59:9-16

Edlund A, Nichols PD, Roffey R, White DC (1985) Extractable and lipopolysaccharide fatty acid and hydroxy acid profiles from Desulfovibrio species. J Lipid Res 26:982-988

Erridge C, Bennett-Guerrero E, Poxton IR (2002) Structure and function of lipopolysaccharides. Microbes Infect 4:837-851

Fox JG, Dewhirst FE, Fraser GJ, Paster BJ, Shames B, Murphy JC (1994) Intracellular Campylobacter-like organism from ferrets and hamsters with proliferative bowel disease is a Desulfovibrio sp. J Clin Microbiol 32:1229-1237

Gaylarde CC, Beech IB (1996) Short communication: lipopolysaccharide composition of Desulfovibrio cell. World J Microbiol Biotechnol 12:113-114

Gibson GR, Cummings JH, Macfarlane GT (1991) Growth and activities of sulphate-reducing bacteria in gut contents of healthy subjects and patients with ulcerative colitis. FEMS Microbiol Ecol 86:103-112

Goldstein EJ, Citron DM, Peraino VA, Cross SA (2003) Desulfovibrio desulfuricans bacteremia and review of human Desulfovibrio infections. J Clin Microbiol 41:2752-2754

Imoto M, Kusumoto S, Shiba T, Naoki H, Iwashita T, Rietschel ET, Wollenweber E, Galanos C, Luderitz O (1983) Chemical structure of E. coli lipid A: linkage site of acyl groups in the disaccharide backbone. Tetrahedron Lett 24:4017-4020

Johnson KG, Perry MB (1976) Improved techniques for the preparation of bacterial lipopolysaccharides. Can J Microbiol 22:29-34

Lodowska J, Wolny D, Węglarz L, Dzierżewicz Z (2007) Heterogenność strukturalna lipidu A bakterii Gram-ujemnych. Postepy Hig Med Dosw 61:106-121

McDougall R, Robson J, Paterson D, Tee W (1997) Bacteremia caused by a recently described novel Desulfovibrio species. J Clin Microbiol 35:1805-1808

Porschen RK, Chan P (1977) Anaerobic vibrio-like organisms cultured from blood: Desulfovibrio desulfuricans and Succinivibrio species. J Clin Microbiol 5:444-447

Postgate JR (1984) The sulphate reducing bacteria, 2nd edn. Cambridge University Press, London

Raetz CR, Reynolds CM, Trent MS, Bishop RE (2007) Lipid A modification systems in gram-negative bacteria. Annu Rev Biochem 76:295-329

Rietschel ET, Kirikae T, Schade FU, Mamat U, Schmidt G, Loppnow H, Ulmer AJ, Zahringer U, Seydel U, Di Padova F et al (1994) Bacterial endotoxin: molecular relationships of structure to activity and function. FASEB $\mathrm{J}$ 8:217-225

Rybka J, Gamian A (2006) Determination of endotoxin by the measurement of the acetylated methyl glycoside derivative of Kdo with gas-liquid chromatography-mass spectrometry. J Microbiol Methods 64:171-184

Shukla SK, Reed KD (2000) Desulfovibrio desulfuricans bacteremia in a dog. J Clin Microbiol 38:1701-1702

Ulmer AJ, Rietschel ET, Zahringer U, Heine H (2002) Lipopolysaccharide: structure, bioactivity, receptors, and signal transduction. Trends Glycosci Glyc 14:53-68

Węglarz L, Dzierżewicz Z, Orchel A, Szczerba J, Jaworska-Kik M, Wilczok T (2003a) Biological activity of Desulfovibrio desulfuricans lipopolysaccharide evaluated via interleukin- 8 secretion by Caco-2 cells. Scand J Gastroenterol 38:73-79 
Węglarz L, Dzierżewicz Z, Skop B, Orchel A, Parfiniewicz B, Wisniowska B, Swiatkowska L, Wilczok T (2003b) Desulfovibrio desulfuricans lipopolysaccharides induce endothelial cell IL-6 and IL-8 secretion and E-selectin and VCAM-1 expression. Cell Mol Biol Lett 8:991-1003

Węglarz L, Parfiniewicz B, Mertas A, Kondera-Anasz Z, JaworskaKik M, Dzierżewicz Z, Świątkowska L (2006) Effect of endotoxin isolated from Desulfovibrio desulfuricans soil and intestinal strains on the secretion of TNF- $\alpha$ by human mononuclear cells. Pol J Environ Stud 15:615-622

Wollenweber HW, Rietschel ET (1990) Analysis of lipopolysaccharide (lipid A) fatty acids. J Microbiol Meth 11:195-211
Wollenweber HW, Broady KW, Luderitz O, Rietschel ET (1982) The chemical structure of lipid A. Demonstration of amide-linked 3-acyloxyacyl residues in Salmonella minnesota Re lipopolysaccharide. Eur J Biochem 124:191-198

Wollenweber HW, Schlecht S, Luderitz O, Rietschel ET (1983) Fatty acid in lipopolysaccharides of Salmonella species grown at low temperature. Identification and position. Eur $\mathrm{J}$ Biochem 130:167-171

Wollenweber HW, Seydel U, Lindner B, Luderitz O, Rietschel ET (1984) Nature and location of amide-bound (R)-3-acyloxyacyl groups in lipid A of lipopolysaccharides from various gramnegative bacteria. Eur J Biochem 145:265-272 